\title{
Testicular and epididymal sperm reserves of crossbred European boars raised and maintained in the humid tropics
}

\author{
G. N. Egbun ke and A. O. Elemo \\ Department of Animal Science, University of Ibadan, Ibadan, Nigeria
}

\begin{abstract}
Summary. The testicular and epididymal sperm reserves of 32 adult crossbred European boars (mean age 17.4 months, range 15-21 months) raised and maintained in Ibadan, Nigeria were $43.77 \times 10^{9}$ and $207.20 \times 10^{9}$ cells respectively, and were correlated $(P<0.01)$ with age and organ weight. The distribution of spermatozoa in the epididymis was 16,6 and $78 \%$ in the caput, corpus and cauda epididymidis respectively. The testicular and epididymal sperm reserves were correlated $(P<0.05)$, suggesting that sperm production and storage are associated. All the values studied were comparable with those reported for boars kept in temperate climates.
\end{abstract}

\section{Introduction}

In the bid to increase and improve swine production in the tropics, the use of improved imported breeds of pigs is being steadily intensified, and in such a situation there may be a tendency to overuse the animals, especially the boars. The reproductive aspects of swine production under tropical conditions have received little attention, but a sound knowledge of this important part of animal production and its interaction with the environment is essential for a maximum and rational utilization of the breeding stock.

High ambient temperatures have been reported to affect reproduction in swine (Corteel, Signoret \& du Mesnil du Buisson, 1964; Thibault et al., 1966), spermatogenesis is greatly impaired (Mazzarri, du Mesnil du Buisson \& Ortavant, 1968) and the morphology and physiology of the ejaculated spermatozoa, presumably those stored in the epididymis, are adversely affected (Mazzarri et al., 1968; McNitt \& First, 1970). However, Egbunike \& Steinbach (1976) did not observe any difference in sperm production rates in adult boars raised in temperate and tropical climates and Steinbach (1976) found that the quality of the ejaculates of boars in a tropical environment was comparable to that of boars kept in temperate climatic conditions.

The present study was to determine the gonadal sperm reserves and the storage capacity of the epididymis of improved boars under humid tropical climatic conditions.

\section{Materials and Methods}

The study involved 32 adult crossbred boars (Large White $\times$ Hampshire) with an average age of $17 \cdot 4$ months (range, 15-21 months) and weighing between 95 and $150 \mathrm{~kg}$. All the animals were housed as reported earlier (Egbunike \& Steinbach, 1972) and provided with standard breeder's ration and unlimited water. After slaughter between January and May 1977, the reproductive tracts were quickly dissected and taken to the laboratory for further processing.

The testes and epididymides were then carefully trimmed, weighed and homogenized according to the methods applied by Igboeli \& Rakha (1971) and Egbunike, Holtz \& Smidt (1976), while sperm concentrations were determined by direct haemocytometer count after $1: 40(\mathrm{v} / \mathrm{v})$ dilution in $0 \cdot 154$ $\mathrm{M}-\mathrm{NaCl}$ (Egbunike et al., 1976). The data were subjected to standard statistical analysis according to Steel \& Torrie (1960).

Since the duration of sampling was short and the daily changes in the ambient temperatures and photoperiod were small $\left(<0.3^{\circ} \mathrm{C}\right.$ and $11 \mathrm{~min}$ per month respectively) no analysis for seasonal effects was carried out. 


\section{Results and Discussion}

The results are summarized in Table 1 and are compared with values reported in the literature for boars in temperate climates in Table 2 . The ratio of left to right testicular weight agrees with the results obtained with German Landrace boars by Egbunike, Holtz, Endell \& Smidt (1975) and with Yorkshire and Lacombe boars by Swierstra \& Rahnefeld (1967) and Swierstra (1968). The average paired testes weight was much lower than that reported by Swierstra (1968) for even younger boars in Canada (Table 2). These differences may have been due to the differences in the growth rates of pigs under the temperate and tropical climates (Egbunike \& Steinbach, 1976). The weight distribution in the epididymis was similar to that of German Landrace boars (Egbunike et al., 1975) with the cauda epididymidis accounting for half of the total epididymal weight followed by the caput and corpus epididymidis (Table 2).

Table 1. Testicular and epididymal sperm reserves of crossbred boars raised and maintained in the humid tropics

\begin{tabular}{|c|c|c|c|}
\hline Trait & Right & Left & Total \\
\hline \multicolumn{4}{|l|}{ Weights (g) } \\
\hline Testis & $259 \cdot 27 \pm 12 \cdot 88$ & $260 \cdot 50 \pm 12.04$ & $519.77 \pm 30.22$ \\
\hline \multicolumn{4}{|l|}{ Epididymis } \\
\hline Caput & $28 \cdot 87 \pm 2 \cdot 71$ & $30 \cdot 81 \pm 2.57$ & $59.68 \pm 3.81$ \\
\hline Corpus & $10.45 \pm 1.34$ & $10.91 \pm 1.62$ & $21 \cdot 36 \pm 2 \cdot 59$ \\
\hline Cauda & $41 \cdot 24 \pm 3 \cdot 52$ & $43.45 \pm 3.45$ & $84 \cdot 69 \pm 4 \cdot 18$ \\
\hline \multicolumn{4}{|c|}{ Sperm reserves $\left(\times 10^{9}\right)$} \\
\hline Testis & $19 \cdot 70 \pm 2.03$ & $24-07 \pm 2.51$ & $43.77 \pm 3.45$ \\
\hline \multicolumn{4}{|l|}{ Epididymis } \\
\hline Caput & $15.91 \pm 1.83$ & $17 \cdot 24 \pm 1 \cdot 85$ & $33 \cdot 15 \pm 2 \cdot 46$ \\
\hline Corpus & $6.09 \pm 0.66$ & $6.34 \pm 0.58$ & $12.43 \pm 1.09$ \\
\hline Cauda & $79 \cdot 19 \pm 6.71$ & $82.43 \pm 7.08$ & $161.62 \pm 13.52$ \\
\hline
\end{tabular}

As with the testicular and epididymal weights, there were more spermatozoa in the left organ than in the right although the differences were insignificant. There was an effect of age on the epididymal and gonadal sperm numbers (Table 3). The gonadal sperm numbers were comparable to those of younger Landrace boars under temperate conditions, but the latter had much lower epididymal sperm numbers (Egbunike et al., 1975). However, consideration on a per gram basis showed that there was no difference between the two groups of boars (Table 2), confirming the close relationship between organ weight and sperm reserves as reported by Swierstra (1968) and Egbunike et al. (1975).

The disparity observed between the percentages of the total spermatozoa in each of the three epididymal compartments in this study and those reported by Swierstra (1970) may have been due to the effect of the ejaculation regimen imposed on the latter boars, i.e. every $72 \mathrm{~h}$ for 15 weeks.

A summary of the correlations between organ weights and sperm reserves is shown in Table 3 . The high correlation between the organ weights and the sperm reserves suggests that the former can serve as an index of the latter and confirms earlier findings (Swierstra, 1968; Egbunike et al., 1975). That sperm production and sperm storage are related was implied by the correlation between gonadal and epididymal sperm numbers although this relation was not observed for younger German Landrace boars (Egbunike et al., 1975), perhaps because their storage capacity was still growing. The age of the boar clearly influences the weight of the organs and their sperm reserves (Table 3), as found for boars kept under temperate climatic conditions (Egbunike et al., 1975).

The sperm production rate of our crossbred boars was $10.02 \times 10^{9}$ spermatozoa/day when estimated from the testicular sperm numbers by using a divisor of 4.37 (Amann, 1970). Thus the storage capacity of the epididymis may be assumed to accommodate the spermatozoa produced over about 20 days, a greater capacity than that of the 11.5 days' production deduced for younger boars in a temperate climate (Egbunike et al., 1975). This further suggests a biggerastorage capacity of the $45 \mathrm{AM}$ 
Table 2. Testicular and epididymal characteristics in crossbred boars kept in humid tropical climates compared with those for German Landrace (GL) and Yorkshire $(Y)$ and Lacombe $(L)$ boars kept in temperate climates

\begin{tabular}{|c|c|c|c|c|}
\hline Trait & $\begin{array}{c}\text { Crossbred tropical } \\
\text { boars }\end{array}$ & $\begin{array}{c}\text { Temperate climate } \\
\text { boars }\end{array}$ & Breed & Reference \\
\hline \multicolumn{5}{|l|}{ Testis } \\
\hline \multirow[t]{3}{*}{ Paired weight (g) } & 519.8 (17.4 months) & 739.0 (11.2 months $)+$ & $\mathrm{Y}, \mathrm{L}$ & Swierstra, 1968 \\
\hline & & 783.7 (8.5 months) & $\mathbf{Y}, \mathbf{L}$ & Swierstra, 1970 \\
\hline & & $464 \cdot 3$ (8.3 months) & GL & Egbunike et al., 1975 \\
\hline \multirow[t]{3}{*}{ Left : right } & $100: 99 \cdot 53$ & $100: 96 \cdot 70$ (9.2 months) & $\mathbf{Y}, \mathbf{L}$ & Swierstra \& Rahnefeld, 1967 \\
\hline & & $100: 97.07$ & $\mathbf{Y}, \mathbf{L}$ & Swierstra, 1968 \\
\hline & & $100: 95 \cdot 91$ & GL & Egbunike et al., 1975 \\
\hline \multicolumn{5}{|l|}{ Gonadal spermatozoa } \\
\hline \multirow[t]{2}{*}{$\left(\times 10^{9}\right)$} & $43 \cdot 77$ & $40 \cdot 74$ & GL & Egbunike et al., 1975 \\
\hline & & $49 \cdot 50$ ( 7.7 months) & GL & Egbunike et al., 1976 \\
\hline \multirow{3}{*}{$\begin{array}{l}\text { Left : right } \\
\text { Spermatozoa } / g \\
\text { testis }\left(\times 10^{6}\right)\end{array}$} & $100: 81 \cdot 84$ & $100: 84 \cdot 93$ & GL & Egbunike et al., 1975 \\
\hline & & & & \\
\hline & $84 \cdot 21$ & $87 \cdot 74$ & GL & Egbunike et al., 1975 \\
\hline \multicolumn{5}{|l|}{ Epididymis* } \\
\hline Paired weight(g) & $65 \cdot 73$ & $104 \cdot 94$ & GL & Egbunike et al., 1975 \\
\hline Left : right & $100: 94 \cdot 59$ & $100: 95 \cdot 24$ & GL & Egbunike et al., 1975 \\
\hline Caput $(\%)$ & 36 & 34 & GL) & \\
\hline Corpus $(\%)$ & 13 & 14 & GL & Egbunike et al., 1975 \\
\hline Cauda $(\%)$ & 51 & 52 & GL & \\
\hline Epididymal & $207 \cdot 20$ & $161 \cdot 20$ & $\mathbf{Y}, \mathbf{L}$ & Swierstra, $1970\left(17^{\circ} \mathrm{C}\right)$ \\
\hline \multirow{2}{*}{ Spermatozoa $\left(\times 10^{9}\right)$} & & $212 \cdot 40$ & $\mathbf{Y , L}$ & Swierstra, 1970 (below $-15^{\circ} \mathrm{C}$ ) \\
\hline & & $107 \cdot 66$ & GL & Egbunike et al., 1975 \\
\hline Left :right & $100: 95 \cdot 45$ & $100: 92 \cdot 25$ & GL & Egbunike et al., 1975 \\
\hline Caput $(\%)$ & 16 & $16(28 \cdot 4)$ & GL & Egbunike et al., 1975 \\
\hline Corpus $(\%)$ & 6 & $10(18 \cdot 5)$ & $(\mathbf{Y}, \mathbf{L})$ & (Swierstra, 1970, in parentheses) \\
\hline Cauda $(\%)$ & 78 & $74(52 \cdot 8)$ & & \\
\hline \multicolumn{5}{|l|}{ Spermatozoa/g } \\
\hline epdidymis $\left(\times 10^{9}\right)$ & $1 \cdot 25$ & 1.03 & & \\
\hline
\end{tabular}

* Ductus deferens not included in the data from the literature.

Table 3. Correlation coefficients

\begin{tabular}{lccccc}
\hline \multicolumn{1}{c}{ Variables } & 1 & 2 & 3 & 4 & 5 \\
\hline 1. Age of boar & - & $0.72^{* *}$ & $0.69^{* *}$ & $0.75^{* *}$ & $0.68^{* *}$ \\
2. Paired testes weight & - & - & $0.68^{* *}$ & $0.80^{* *}$ & $0.61^{* *}$ \\
3. Weight of epididymis & - & - & - & $0.64^{* *}$ & $0.84^{* *}$ \\
4. Testicular sperm reserves & - & - & - & - & $0.30^{*}$ \\
5. Epididymal sperm reserves & - & - & - & - & - \\
\hline
\end{tabular}

$* P<0.05, * * P<0.01$

epididymis of the older boars. If output is about $29.3 \times 10^{9}$ spermatozoa every $48 \mathrm{~h}$ (Swierstra, 1968) and if it is assumed that most of the spermatozoa in the ejaculate come from the cauda epididymidis, the sperm reserve in the epididymis of these crossbred boars would comfortably cater for 5 consecutive ejaculations. This estimate would, however, also depend on factors such as the sperm production rate, the rate of movement of spermatozoa from the rete testis to the epididymis, the frequency of ejaculation and the rate of epididymal absorption of spermatozoa.

It can be inferred from the present results that sperm production and sperm storage in boars raised under humid tropical conditions follow the same pattern as in boars kept in temperate regions. 
These findings therefore do not support those of Mazzarri et al. (1968) and McNitt \& First (1970). These workers did, however, use local or whole-body heating techniques which would have resulted in testicular temperatures of $2-7^{\circ} \mathrm{C}$ higher than those of the $38-39^{\circ} \mathrm{C}$ temperature which applies in normal boars (Waites \& Setchell, 1969), mainly as a result of the heat-exchange mechanism between the internal spermatic artery and the pampiniform veins. Such high testicular temperatures negate the effect of the descent of the testes into the scrotum in mammals and hence result in impaired spermatogenesis (Chowdhury \& Steinberger 1964) and a high incidence of abnormal spermatozoa (McNitt \& First, 1970). The morphology of the spermatozoa was not examined in this study, but Steinbach (1976) has found that the numbers of morphologically abnormal spermatozoa in the ejaculates of similar boars were within the range reported for boars in temperate climates. Moreover, animals which have been used in 'hot room' experiments in temperate areas are not adapted to high temperatures in the ways that boars raised and maintained in the tropics over many generations have been.

The present paper demonstrates that the crossbred European boars used have become adapted to the level of heat stress imposed on them by the natural humid tropical climate and that further reproductive improvement rests on the improvement in the growth rate of the reproductive organs which is associated with increased growth rate and improved management.

\section{References}

Amann, R.P. (1970) Sperm production rates. In The Testis, vol. I, pp. 443-482. Eds A. D. Johnson, W. R. Gomes \& N. L. VanDemark. Academic Press, New York.

Chowdhury, A.K. \& Steinberger, E. (1964) A quantitative study of the effect of heat on the germinal epithelium of rat testes. Am.J. Anat. 115, 509-524.

Corteel, J., Signoret, J.P. \& du Mesnil du Buisson, F. (1964) Variations saisonnières du la reproduction de la reproduction de la truie et facteurs favorisant l'anoestrus temporale. Proc. 5th Int. Congr. Anim. Reprod. \& A. I., Trento, Vol. III, 536-539.

Egbunike, G.N. \& SteinbaCh, J. (1972) Age changes in the testicular function of boars reared in a tropical environment. Proc. 7th Int. Congr. Anim. Reprod. \& A. I., Munich, Vol. III, 2087-2090.

Egbunike, G.N. \& Steinbach, J. (1976) Comparative studies of sperm production in boars raised in temperate and tropical climates. Proc. 8th Int. Congr. Anim. Reprod. \& A. I., Cracow, Vol. III, 42-45.

Egbunike, G.N., Holtz, W., Endell, W. \& Smidt, D. (1975) Reproduuctive capacity of German Landrace boars. I. Gonadal and extra-gonadal sperm reserves. Zuchthygiene 10, 184-187.

Egbunike, G.N., Holtz, W. \& Smidt, D. (1976) Reproductive capacity of German Landrace boars. II. Sperm production rates as determined by quantitative testicular histology and from gonadal sperm reserves. Zuchthygiene 11, 35-37.

IgBoELI, G. \& RAKHA, A.M. (1971) Gonadal and extragonadal sperm reserves of indigenous Central African bulls.J. Reprod. Fert. 25, 107-109.
Mazzarri, D., du Mesnil du Buisson, F. \& Ortavant, R. (1968) Action of temperature on spermatogenesis, sperm production and fertility of the boar. Proc. 6th Int. Congr. Anim. Reprod. \& A.I., Paris, Vol. I, 305-308.

MCNitT, J.I. \& FirsT, N.L. (1970) Effects of 72-hour heat stress on semen quality in boars. Int. J. Biometeor. 14, 373-380.

Steel, R.G.D. \& Torrie, J.H. (1960) Principles and Procedures of Statistics. McGraw-Hill Book Co. Inc., New York.

SteINBACH, J. (1976) Reproductive performance of high-producing pigs under tropical conditions. Wld Anim. Rev. 19, 43-47.

SWIERSTRA, E.E. (1968) A comparison of spermatozoa production and spermatozoa output of Yorkshire and Lacombe boars. J. Reprod. Fert. 17, 459-469.

SwiErstra, E.E. (1970) The effect of low ambient temperatures on sperm production, epididymal sperm reserves and semen characteristics of boars. Biol. Reprod. 2, 23-28.

Swierstra, E.E. \& Rahnefeld, G.W. (1967) Semen and testis characteristics in young Yorkshire and Lacombe boars. J. Anim. Sci. 26, 149-157.

Thibault, C.M., Courot, M., Martinet, L., Mauleon, P., du Mesnil du Buisson, F., Ortayant, R., Pelletier, J. \& Signoret, J.P. (1966) Regulation of breeding season and estrous cycle by light and external stimuli in some mammals. J. Anim. Sci. 25 (Suppl), 119-142.

Waites, G.M.H. \& Setechell, B.P. (1969) Physiology of the testis, epididymis and scrotum. Adv. Reprod. Physiol. 4, 1-63.

Received 3 January 1978 